\title{
The science commons in health research: structure, function, and value
}

\author{
Robert Cook-Deegan
}

Published online: 24 January 2007

(C) Springer Science+Business Media, LLC 2007

\section{Erratum to: J Technol Transfer DOI 10.1007/s10961-006-9016-9}

The publisher apologizes for the following errors that appeared in the online article.

The reference year for National Research Council should be 1988 (not 1998). This appears in the reference section and on line six under Sect. 4 "Public and private genomics in mortal combat'.

The Nelson (2006) reference is incorrect. The correct reference is:

Nelson, R. R. (2004). The market economy and the science commons. Research Policy, 33, 455-471.

The online version of the original article can be found at http://dx.doi.org/10.1007/s10961-006-9016-9

R. Cook-Deegan $(\bowtie)$

Center for Genome Ethics, Law and Policy, Institute for Genome Sciences and Policy and Sanford Institute of Public Policy and Duke Medicine School, Duke University, 242 North Building, Durham, NC 27708-0141, USA

e-mail: gelp@duke.edu 